\title{
UMA TEORIA PURA DA SOCIEDADE: \\ os fundamentos da crítica kelseniana à Sociologia do Direito
}

\section{Nelson do Vale Oliveira}

Curso: Mestrado em Sociologia

Data de defesa da dissertação: 25 de março de 2005

Orientador: Prof. Dr. Luis Augusto Sarmento de Gusmão

\section{Resumo}

Hans Kelsen formulou diversas críticas à Sociologia do Direito. Dentre estas se contam a de que tal sociologia incorre em jusnaturalismo, a de que confunde "ser" e "dever ser", personificando normas, e a de que é incapaz de definir corpos coletivos. Estas críticas têm como fundamento o mesmo corpo de premissas que levam à Teoria Pura do Direito. Tais premissas compõem uma Teoria da Sociedade: a Sociedade é um conjunto de elementos vinculados normativamente, tais elementos formam subconjuntos desconexos entre si, mas coerentes internamente e têm uma estrutura interna determinada.

A natureza normativa da Sociedade implica uma dicotomia nos estudos acerca da vida social, já que não se pode logicamente deduzir fatos de normas e vice versa. Desta forma tem-se uma ciência social causal e uma ciência social normativa. Aquela estuda o comportamento concreto de seres humanos, ainda que dotado de sentido subjetivo. A última estuda o conjunto de normas sociais enquanto sentido objetivo, independente dos seres humanos individuais. 
Palavras-chave: Sociologia do Direito, teoria pura do Direito, norma, estrutura normativa, Hans Kelsen, Max Weber, Eugen Erlich, Nicklas Luhmann, Durkheim, ordem normativa. 